\title{
Refugees, asylum seekers and COVID-19: Canada needs to do more to protect at-risk refugees during the current pandemic
}

\author{
Ehsan Jozaghi ${ }^{1,2}$ (D) Azim Dahya ${ }^{3,4}$
}

Received: 25 May 2020 / Accepted: 2 June 2020 / Published online: 17 June 2020

(C) The Canadian Public Health Association 2020

Dear Editor,

As the number of global confirmed infection rates linked to COVID-19 has now surpassed 5 million, and at least 300,000 confirmed mortalities have been recorded, many human rights organizations have already raised the alarm about the plight of refugees and asylum seekers (Evans, 2020). This is particularly important as the number of asylum seekers and refugees displaced due to war and conflicts has reached its highest level since World War II (United Nations High Commissioner for Refugees, 2017a,b). At the same time, many refugees faced numerous health-related concerns even before the COVID-19 pandemic, such as infectious outbreaks that are caused by a lack of essential health care and social services (Sharara, 2014). The most commonly reported health outbreaks in refugee camps prior to the COVID-19 pandemic are measles, hepatitis A or B, leishmaniasis, poliomyelitis, meningitis, scabies, typhoid, tuberculosis, cholera, and dysentery, as well as diseases spread by rats and mosquitoes (Sharara, 2014). Mental health and substance userelated disorders linked to refugees and asylum seekers do not require elucidating (Jozaghi, 2019; Langlois et al., 2016).

As COVID-19 cases are being reported at an increasing rate in many refugee camps (Tinmaung, \& Jaafar, 2020; Carassava, 2020), we would like to raise concerns about the conditions at many refugee camps that may place elderly individuals and people with pre-existing health conditions at an inevitable risk

Ehsan Jozaghi

eja2@sfu.ca

1 The British Columbia Centre for Disease Control, 655 W 12th Ave, Vancouver, BC V5Z 4R4, Canada

2 The School of Population and Public Health, University of British Columbia, E Mall, 2206 E Mall, Vancouver, BC V6T 1Z3, Canada

3 Muslim Food Bank \& Community Services Society, 104 - 12941 115 Ave, Surrey, BC V3R 0E2, Canada

4 ASPIRE Community Services, Richmond, Surrey, and Mississauga, British Columbia \& Ontario, Canada of death. While the conditions at many refugee camps do not need elucidating, it is important to note that many refugee camps are located in poor countries that would have problems meeting the demands of their own populations' health care needs under normal circumstances. For example, in Bangladesh, which is home to nearly a million Rohingya refugees, there are only 2000 ventilators for all Bangladeshis (Thomson Reuters, 2020). At the same time, many refugee camps do not have access to water or soap, and social distancing and self-isolation are not possible because the population density levels in many camps are the highest in the world (e.g., 40,000 to 70,000 people/ $\mathrm{km}^{2}$ in a refugee camp, as compared with New York, which contains 6000 people $/ \mathrm{km}^{2}$ ) (Chotiner, 2020).

While Canada is facing its own challenges in combatting and protecting vulnerable and at-risk populations, the federal government needs to increase its aid to non-government agencies, including, but not limited to, Médecins Sans Frontières, who are directly involved on the ground with many at-risk populations across the globe (France24, 2020). Currently, Canada's humanitarian assistance is well below other nations in the Organisation for Economic Co-operation and Development (Sevunts, 2018). For example, Canada currently spends $0.26 \%$ of its gross national income, which is far below the $0.32 \%$ of the other 29 nations on the Development Assistance Committee (Sevunts, 2018). Therefore, during the current pandemic, the federal government needs to at least reach the $0.7 \%$ target established by the United Nations resolution in the 1970s (Sevunts, 2018).

Acknowledgements Caimen Yen's editorial assistance is acknowledged on this letter.

\section{References}

Evans, M. (2020). Aid workers brace for impact of coronavirus in refugee camps. CBC News. Accessed from: https://www.cbc.ca/news/ 
world/aid-workers-brace-for-impact-of-coronavirus-in-refugeecamps- 1.5506172

Carassava, A. (2020). Greece tightens COVID controls at refugee camp. Voice of America. Accessed from: https://www.voanews.com/ europe/greece-tightens-covid-controls-refugee-camp

Chotiner, I. (2020). The danger of COVID-19 for refugees. The New Yorker. Accessed from: https://www.newyorker.com/news/q-anda/the-danger-of-covid-19-for-refugees

France24 (2020). Doctors without borders warns of Covid-19 'catastrophe' in war-torn Yemen. Accessed from: https://www.france24. com/en/20200521-doctors-without-borders-warns-of-covid-19catastrophe-in-warn-torn-yemen

Jozaghi, E. (2019). A call for action for mental health intervention and support for refugees who escape internal conflicts or war. Canadian Journal of Public Health, 110(3), 380-381.

Langlois, E. V., Haines, A., Tomson, G., \& Ghaffar, A. (2016). Refugees: towards better access to health-care services. Lancet, 387(10016), 319-321.

Sevunts, L. (2018). Canada's foreign aid spending still below OECD average after budget boost. CBC News. Accessed from: https:// www.cbc.ca/news/politics/canada-foreign-aid-budget-1.4556537
Sharara, S. L. (2014). Kanj SS. War and infectious diseases: challenges of the Syrian civil war. PLoS Pathogens, 10(11), e1004438.

Tinmaung, R., \& Jaafar, B. (2020). How Canada can help the Rohingya refugees fend off COVID-19. Ottawa Citizen. Accessed from: https://ottawacitizen.com/opinion/tinmaung-and-jaafar-howcanada-can-help-the-rohingya-refugees-fend-off-covid-19/

Thomson Reuters. (2020). 1st COVID-19 case detected in Rohingya camps in Bangladesh. CBC News. Accessed from: https://www. cbc.ca/news/world/rohingya-bangladesh-coronavirus-1.5571007

United Nations High Commissioner for Refugees. (2017a). Figures at a glance, global trends 2015. Available at: http://www.unhcr.org/ figures-at-a-glance.html.

United Nations High Commissioner for Refugees. (2017b). Global trends, forced displacement in 2017. Available at: http://www. unhcr.org/5b27be547.pdf

Publisher's note Springer Nature remains neutral with regard to jurisdictional claims in published maps and institutional affiliations. 